УДК 656.072

\title{
ОСОБЛИВОСТІ РОЗВИТКУ ПАСАЖИРСЬКИХ ПЕРЕВЕЗЕНЬ НА ЗАЛІЗНИЧНОМУ ТРАНСПОРТІ УКРАЇНИ
}

\author{
Полякова О.М., к.е.н., доцент, \\ Іванченко Ю.В., махістр (УкрДУЗТ)
}

В статті досліджено сучасні проблеми розвитку пасажирських перевезень, визначено напрями забезпечення ефективної діяльності підприємств пасажсирського комплексу залізничного транспорту. Відзначено, щзо проведення гнучкої політики у сфері управління пасажирськими перевезеннями можливе за умов збереження державної власності у сфері залізничного транспорту, забезпечення прозорості та передбачення субсидіювання пасажирських перевезень з державного бюджету.

Ключові слова: пасажирські перевезення, розвиток пасажирських перевезень, підприсмства пасажирського комплексу, залізничний транспорт, реформування, забезпечення ефективності пасажирських перевезень.

\section{ОСОБЕННОСТИ РАЗВИТИЯ ПАССАЖИРСКИХ ПЕРЕВОЗОК НА ЖЕЛЕЗНОДОРОЖНОМ ТРАНСПОРТЕ УКРАИНЫ}

\author{
Полякова Е.Н., к.э.н., доцент, \\ Иванченко Ю.В., магистр (УкрГУЖТ)
}

\begin{abstract}
В статье исследованы современные проблемы развития пассажирских перевозок, определень направления обеспечения эффективной деятельности предприятий пассажирского комплекса железнодорожного транспорта. Отмечено, что проведение гибкой политики в области управления пассажсирскими перевозками возможно при условии сохранения государственной собственности в сфере железнодорожного транспорта, обеспечения прозрачности и субсидирования пассажсирских перевозок из государственного бюджета.
\end{abstract}

Ключевые слова: пассажирские перевозки, развитие пассажирских перевозок, предприятия пассажирского комплекса, жжелезнодорожный транспорт, реформирование, обеспечение эффективности пассажирских перевозок.

\section{PECULIARITIES OF DEVELOPMENT OF PASSENGER TRANSPORTATION AT RAILWAY TRANSPORT OF UKRAINE}

\author{
Polyakova E.N, Candidate of Economics, associate professor, \\ Ivanchenko Yu.V. master (USURT)
}

In the article modern problems of development of passenger transportations are investigated, directions of maintenance of effective activity of the enterprises of a passenger complex of a railway transportation are defined. It is noted that the availability of transport services has long-term social and macroeconomic consequences, without which intensive economic development of the country is impossible. It is proved that the implementation of a flexible policy in the field of passenger transportation management is possible provided that state

(C) Полякова О.М., Іванченко Ю.В, 
ownership in the sphere of railway transport is maintained, transparency and subsidizing of passenger transportation from the state budget are ensured.

Keywords: passenger transportation, development of passenger transportation, passenger complex enterprises, railway transport, reforming, ensuring the efficiency of passenger transportation.

Постановка проблеми. Залізничний транспорт - складова частина транспортного сектора економіки країни, що функціонує як складний виробничотехнологічний комплекс. Він займає ведуче місце на ринку транспортних послуг, забезпечуючи перевезення пасажирів переважно в міжміському i приміському сполученнях, а також обслуговуючи зовнішні соціально-економічні зв'язки України.

На долю залізничного транспорту припадає від 5-6\% загального числа перевезених пасажирів, що на перший погляд являє собою досить незначний рівень і висуває галузь тільки на п'яте місце серед інших видів транспорту загального користування. Між тим, 3 урахуванням середньої дальності поїздки пасажирів, значимість залізниць істотно підсилюється. За обсягом пасажирообороту залізничний транспорт складає основу транспортної системи країни, виконуючи понад 33-43\% загальної величини пасажиро-кілометрів [19]. Для порівняння: в країнах Свропейського Союзу, частка залізниць хоч i зростає, але становить $7,4 \%$ за пасажирообігом [18].

Проте за останні десять років частка залізничного транспорту на ринку пасажирських перевезень скоротилась майже на 13\% [2]. Якщо такі тенденції збережуться, то вже через два-три роки Укрзалізниця на ринку пасажирських перевезень буде займати менше $30 \%$, поступившись своїми позиціями автомобільному транспорту та авіації.

Розвитку залізничних пасажирських перевезень в Україні заважають значний знос основних виробничих фондів, невисока якість обслуговування пасажирів, низька швидкість руху, висока собівартість перевезень, відсутність стимулів для зниження витрат і підвищення якості послуг. Причинами низької конкурентоспроможності послуг $\epsilon$ перехресне фінансування пасажирських перевезень, повільність у реагуванні на зміни зовнішнього середовища, відсутність внутрішніх джерел відтворення та стимулів до інноваційного зростання залізничного транспорту. Збитки пасажирської сфери не дають можливості Укрзалізниці придбати у потрібному розмірі рухомий склад, інфраструктуру, здійснити потрібні капіталовкладення. Очевидною $є$ потреба здійснення кардинальних заходів у пасажирській галузі, які б вивели іiі зі збиткового стану чи дали б можливість значно знизити збитки, забезпечити належний рівень транспортної мобільності населення, утримати конкурентні позиції на ринку транспортних послуг. Саме тому виникає необхідність аналізу проблем функціонування підприємств пасажирського комплексу та виявлення напрямів удосконалення їх діяльності.

Аналіз останніх досліджень i публікацій. Виділення невирішених частин загальної проблеми. Вивченню проблем та пошуку шляхів забезпечення сталого розвитку підприємств пасажирського комплексу залізничного транспорту, проблемам реструктуризації підприємств пасажирського комплексу присвячено праці вітчизняних і зарубіжних вчених: А.А, Бакаєва, Ю.С. Бараша, Н.О. Божок, В. Гудкової, В.Л. Диканя, Г.Д. Ейтутіса, Ю.В. Слагіна, Д.М. Козаченка, М.В. Кондратюка, О.О. Матусевич, О.О. Петренко, Т.Ю. Чаркіної, К. Шерепи, О.В. Шраменко та багатьох інших науковців [2-11, 13, 17, 19].

Сформульовані методологічні положення, практичні результати 
досліджень сьогодні, в умовах реформування залізничного транспорту, $\epsilon$ надзвичайно актуальними i в контексті комплексного забезпечення ефективної економічної діяльності підприємств сфери пасажирських перевезень потребують поглиблення.

Постановка завдання. Метою статті є дослідження сучасних особливостей розвитку пасажирських перевезень та визначення напрямів забезпечення ефективної діяльності підприємств пасажирського комплексу залізничного транспорту.

Виклад основного матеріалу. Системний аналіз сучасного стану пасажирського господарства України та тенденцій його розвитку показують, що, незважаючи на його в цілому стабільну роботу, є низка серйозних проблем, які потребують вирішення, а саме:

1) експлуатація застарілого рухомого складу (загальний ступінь зносу рухомого складу становить 82,9 \%);

2) недостатність власних джерел фінансування (амортизація в 4,6 разів менше рівня простого відтворення), відсутність державної підтримки інноваційного розвитку залізничної галузі та низький рівень інвестиційної привабливості, що зумовлює граничний фізичний знос та невідповідність технічного оснащення залізниць сучасним вимогам. Загальна потреба залізничної галузі в інвестиціях на оновлення основних фондів на найближчі п'ять років оцінюється в сумі майже 200 млрд. грн [15];

3) виконання залізницями державних та соціальних функцій (перевезення пільгових категорії пасажирів, утримання малодіяльних збиткових ліній) у поєднанні 3 регульованими урядом низькими тарифами на перевезення пасажирів та відсутність дієвого механізму компенсації збитків від надання суспільно значущих послуг суттєво обмежує можливості техніко-технологічної модернізації залізничного транспорту [11, с. 98];
4) недосконалість механізму обліку й відсутність компенсацій за перевезення пільгових категорій громадян;

5) невідповідність графіків руху потягів попиту на перевезення;

6) недостатня оптимізація складу поїздів;

7) нерозвиненість системи сервісного обслуговування;

8) непрозорий розрахунок собівартості перевезень.

Відповідно, це призводить до таких наслідків, як штучне заниження доходної складової пасажирських перевезень, завищення часу на очікування поїздів, перенаселеність приміських поїздів, низький рівень комфорту, безпеки швидкості руху, низька якість додаткових послуг та ін.

Показник збитковості пасажирських перевезень, що розраховується відношенням отриманих збитків до вкладених ресурсів на здійснення перевезень пасажирів, протягом останніх десяти років не був нижчий рівня 50\%, тобто на кожну витрачену гривню на перевезення залізниці України у середньому отримували 50 коп. збитку. [3].

Розуміння причинно-наслідкових зв'язків збитковості пасажирських перевезень дозволяє визначити основні напрямки забезпечення ефективності пасажирських перевезень (рисунок 1) [17]

Варто зазначити, що ефективність пасажирських перевезень $є$ динамічною категорією, яка залежить як від зовнішнього попиту, економічного стану держави, населення та рівня тарифів й субсидування, так i від пошуку та використання «інструментів» підвищення ефективності функціонування пасажирського комплексу ПАТ «УЗ». Застосування інноваційних підходів організації i технології пасажирських перевезень (реінжиніринг, процесний підхід) дозволяє зменшити технологічні витрати, збільшити кількість та якість додаткових інформаційно-сервісних послуг на всіх етапах обслуговування пасажирів та надає можливості підвищувати 
функціонування пасажирського комплексу в цілому $[5,9]$.

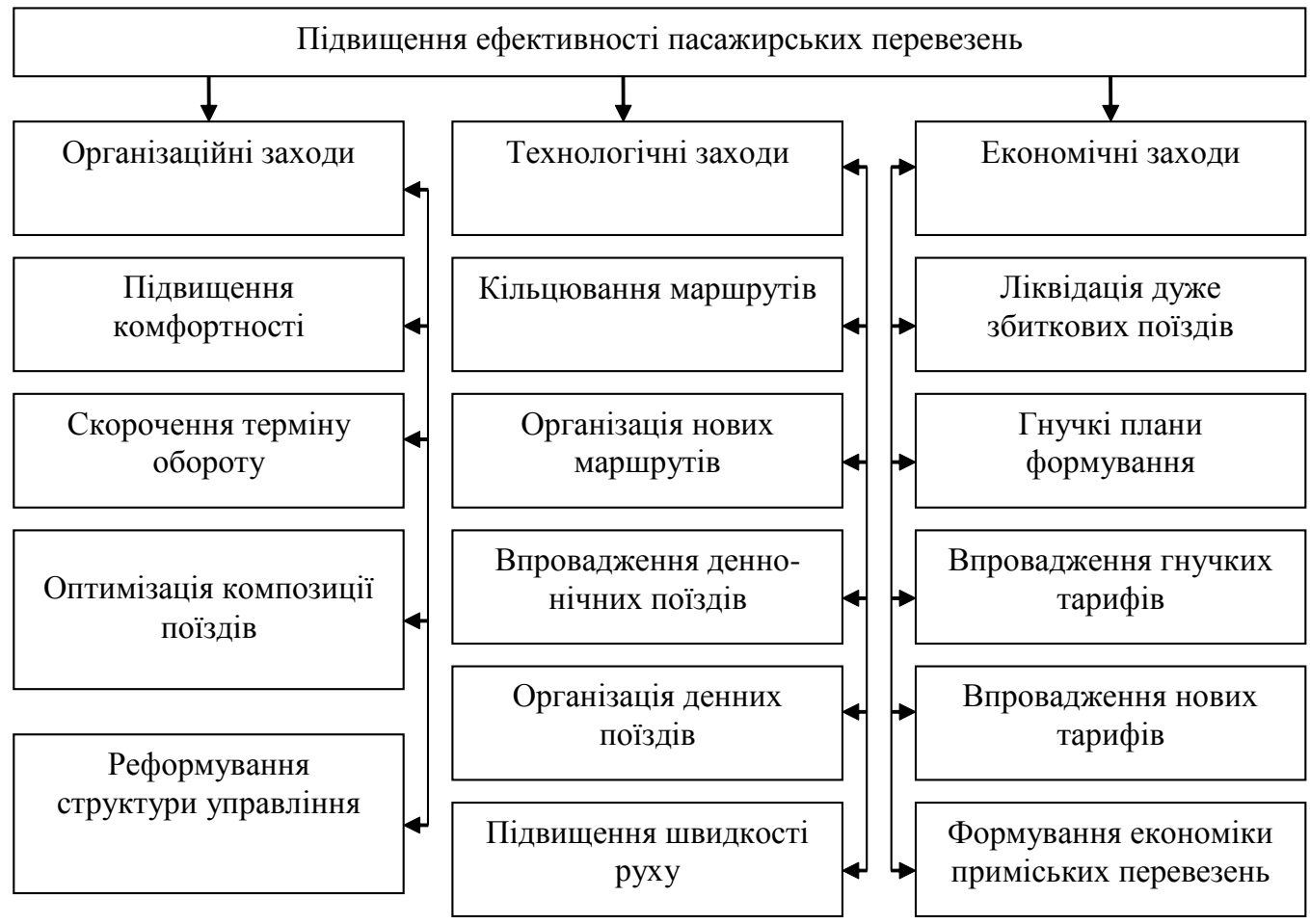

Рис. 1. Напрямки забезпечення ефективності пасажирських перевезень [17, с. 295]

Проте ефективність залізниць не можна вимірювати лише показниками рентабельності. Субсидіювання перевезень відповідає загальноєвропейській практиці: в країнах $Є С$ щорічно витрачається понад $€ 36$ млрд. на покриття збитковості пасажирських перевезень [18]. При цьому розроблено спеціальний регламент, який регулює порядок закупівлі громадських послуг на перевезення пасажирів [10].

Так, в Німеччині щорічні розміри субсидій з державного бюджету залізницям складають $€ 7-12$, у Франції - €11, в Італії $€ 8$, в Іспанії - €5 млрд на рік $[16,18]$. Для порівняння збитковість пасажирських перевезень на залізницях України в 2013 р. склала $€ 0,3$ млрд. В Норвегії з держбюджету покривається 50\% вартості пасажирських перевезень, в Данії - 48\%, Франції - 42\%. В Італії, Німеччині, Чехії та Болгарії пасажири оплачують близько $70 \%$ від вартості поїздки, інше компенсує бюджет. Лише у Великобританії та Нідерландах пасажир оплачує майже повну вартість квитка. При цьому британській уряд виділяе на підтримку залізниць 4-5 млрд. фунтів стерлінгів щорічно [18].

\section{Таким чином, пасажирські} перевезення у світі, як правило, $\epsilon$ дотаційними i, як правило, програють конкурентну боротьбу автомобільному та авіаційному транспорту при оцінці ефективності перевезень виключно економічними показниками.

Варто зазначити, що вітчизняна система пасажирських залізничних перевезень відрізняється від закордонних сукупністю особливостей, які визначають необхідність побудови власної моделі перетворень. За останніх десять років рівень податкових надходжень Укрзалізниці до бюджетів усіх рівнів зріс в 3,5 рази (до 13 млрд. грн), а потреба в закупівлі рухомого складу 3 держбюджету (згідно ст. $103 У$ «Про залізничний транспорт») виконувалась в мізерних обсягах. Тобто перспективи розвитку галузі відступали перед необхідністю наповнення бюджету i утримання соціальних стандартів [18]. 
Реформа залізничного транспорту здійснюється відповідно до Державної цільової програми реформування залізничного транспорту на 2010-2019 рр. та планів імплементації деяких актів законодавства СС у сфері залізничного транспорту [1]. Основною метою реформування залізничного транспорту $\epsilon$ розвиток конкуренції на ринку залізничних перевезень та підвищення ефективності діяльності галузі, в тому числі, і отримання можливості бачити реальну суму перехресного субсидування пасажирських перевезень за рахунок вантажних, а отже, забезпечити державну підтримку збиткових видів перевезень та ліквідувати перехресне субсидіювання [15].

Програма передбачає 3 етапи реформування:

1 етап: розробка нормативноправової бази для реформування, утворення ПАТ «Українська залізниця», розділення функцій господарського та державного управління галуззю, розділення фінансових потоків по видах діяльності, початок реформи тарифної системи;

2 етап: формування вертикальноінтегрованої системи управління (за видами діяльності) в ПАТ «Українська залізниця», формування єдиних правил діяльності для всіх суб'єктів ринку залізничних перевезень, удосконалення тарифної політики, забезпечення вільного ціноутворення у конкурентних секторах ринку транспортних послуг;

3 етап: продовження структурних змін, ліквідація перехресного субсидування пасажирських перевезень за рахунок вантажних, розвиток конкуренції на ринку залізничних перевезень [14].

Так, ПАТ «Укрзалізниця» створила пасажирську компанію та з квітня 2017 року переводить до неї всі виробничі процеси трьох з шести регіональних філій (Південна, Південно-Західна та Львівська). Дана компанія $\epsilon$ вертикально інтегрованою структурою, що здійснюватиме управління системою перевезень. Це дозволить ефективно використовувати парк рухомого складу, забезпечити єдині технології, технічну, тарифну та цінову політики [12].

За думками фахівців, негативними наслідками впровадженої реформи може бути:

- підвищення вартості послуг через допуск приватних перевізників;

- закриття нерентабельних
залізничних маршрутів, зниження мобільності населення;

- погіршення доступу до соціальних послуг залізничників;

- погіршення умов праці у залізничній сфері (переведення працівників підприємств у приватні структури, виведення частини послуг на аутсорсинг) [18].

Таким чином, залізничний транспорт потребує державної підтримки за визначенням. Доступність транспортних послуг має довгострокові соціальні та макроекономічні наслідки, без яких неможливий інтенсивний економічний розвиток країни. Проведення гнучкої політики у сфері управління пасажирськими перевезеннями можливе за умов збереження державної власності у сфері залізничного транспорту, забезпечення прозорості та передбачення субсидіювання пасажирських перевезень 3 державного бюджету в повному обсязі.

Висновки i перспективи подальших досліджень. Загалом виділяють три рівні проблем залізниць в Україні: на системному рівні (економічна модель країни, законодавство, бізнес-модель функціонування залізниці, тарифне регулювання, відсутність інвестицій в інфраструктуру); на рівні організації (негнучка організаційна структура, застаріла модель організації бізнеспроцесів); на базовому рівні (низька компетентність менеджменту, неефективне використання ресурсів, низька мотивація персоналу) [14].

Проведення гнучкої політики у сфері управління пасажирськими перевезеннями можливе за дотримання таких умов: державні дотації мають здійснюватися в 
межах довгострокового державного замовлення, яке готова фінансувати держава; визначення обсягу бюджетних дотацій можливе в результаті забезпечення прозорого розподілу витрат між пасажирськими та вантажними перевезенням; фу функціонування пасажирського комплексу повинно забезпечуватися на базі застосування інноваційних підходів організації і технології пасажирських перевезень.

Перспективними напрямками подальших досліджень $є$ дослідження соціальних аспектів забезпечення ефективної діяльності підприємств пасажирської сфери, а саме розвитку організаційної культури, зв'язків 3 громадськістю, корпоративної соціальної відповідальності.

\section{ПЕРЕЛІК ВИКОРИСТАНИХ ДЖЕРЕЛ}

1 Про затвердження Державної цільової програми реформування залізничного транспорту на 2010-2019 роки [Електронний ресурс]: Постанова КМУ від 16 грудня 2009 p. N1390 [офіц. текст: станом на 02.11.2012 p.]. - Режим доступу: http://zakon1.rada.gov.ua/laws/show/13902009-\%D0\%BF.

2 Божок, Н.О. Методичний підхід щодо визначення привабливості пасажирських перевезень залізничного транспорту [Текст] / Н.О. Божок // Наука та прогрес транспорту. Вісник Дніпропетровського національного університету залізничного транспорту. 2014. - № 2 (50). - С. 31-40.

3 Гудков, О.М. Перспективний механізм фінансування пасажирських перевезень на залізничному транспорті [Текст] / О.М. Гудков // Проблеми економіки транспорту: зб. наук. пр. - Д.: Вид-во Дніпропетр. нац. ун-ту залізн. трансп. ім. акад. В. Лазаряна, 2011. - Вип. 1. - C. 34-39.

4 Гудкова, В. Теоретико-прикладні основи підвищення ефективності економічної діяльності підприємств на ринку транспортного обслуговування населення [Текст] / В. Гудкова // Збірник наукових праць Державного економікотехнологічного університету транспорту: Серія «Економіка і управління». - Вип. 25. К.: ДЕТУТ, 2013. - С. 11-28.

\section{5 Дикань, В.Л. Інформаційні} технології підвищення ефективності пасажирських перевезень [Текст] / В.Л. Дикань, Ю.В. Слагін // Вісник економіки транспорту i промисловості: збірник наукових праць. - Харків: УкрДУЗТ. - 2015. - Вип. 52. - С. 107-110.

6 Дикань, В.Л. Перспективи фінансування приміських пасажирських перевезень в умовах акціонування залізничного транспорту [Текст] / В.Л. Дикань, Ю.В. Слагін // Науковий вісник Міжнародного гуманітарного університету. Серія : Економіка і менеджмент. - 2016. Вип. 16. - С. 46-48.

7 Дикань, В.Л. Повышение эффективности функционирования естественных монополий в условиях рынка (по материалам железнодорожного транспорта) [Текст]: монографія / В.Л. Дикань, Н.И. Данько, Е.В. Шраменко. - Х.: УкрДАЗТ, 2010. - 168 с.

8 Дикань, В.Л. Удосконалення організаційної структури залізничного комплексу України в сучасних умовах [Текст]: монографія / В.Л. Дикань, М. В. Кондратюк. - Х.: УкрДАЗТ, 2010. $190 \mathrm{c}$.

9 Слагін, Ю.В. Сутність та роль інноваційно-логістичних підходів в підвищенні ефективності обслуговування пасажирів [Текст] / Ю.В. Слагін // Вісник економіки транспорту i промисловості: збірник наукових праць. - Харків: УкрДУЗТ. - 2013. - Вип. 44. - С. 44-46.

10 Козаченко, Д.М. Проблеми розвитку пасажирських перевезень залізничним транспортом в Україні / Д.М. Козаченко, Р.Г. Коробйова, А.В. Рубець // Збірник наукових праць ДНУЗТ ім. акад. В. Лазаряна. - 2016. - Вип. 12. - С. 45-50.

11 Матусевич, О.О. Управління економічною ефективністю залізничних 
пасажирських перевезень в умовах трансформаційних змін [Текст]: Дис. ... к.е.н.: 08.00.04 / Матусевич Олексій Олександрович: ДНУЗТ.

Дніпропертовськ, 2015. - 177 с.

12 Пасажирська компанія дозволить більш ефективно реагувати на зростання пасажиропотоку [Електронний ресурс]. Режим доступу: http://www.uz.gov.ua/press_center/up_to_date _topic/447430/

13 Петренко, О.О. Пасажирські залізничні перевезення в Україні: сучасний стан і перспективи розвитку [Текст] / O.O. Петренко // Економіка та управління національним господарством. - 2016. - Вип. 10. - C. 47-52.

14 Реформи залізничного транспорту [Електронний ресурс] // Міністерство інфраструктури України. - Режим доступу: http://mtu.gov.ua/content/reformizaliznichnogo-transportu.html

15 Стратегічний план розвитку залізничного транспорту на період до 2020 року [Електронний ресурс] // Міжнародний техніко-економічний журнал «Українська залізниця». - Режим доступу: http://ukrrailways.com/2-uncategorised/1706strategic-plan-2020-p1.html

16 «Укрзалізниця» значительно поднимет цену на перевозки, если станет частной (28.10.2015) [Електронний ресурс]. - Режим доступу: http://dnpr.com.ua/content/ukrzaliznicyaznachitelno-podnimet-cenu-na-perevozki-eslistanet-chastnoy

17 Чаркіна, Т.Ю. Методика проведення досліджень стосовно підвищення конкурентоспроможності пасажирських перевезень [Текст] / Т.Ю. Чаркіна //Вісник економіки транспорту i промисловості. - 2011. - №36. - С.289-296.

18 Чим Україні загрожує реформа залізниці? (січень 2015) [Електронний ресурс]. - Режим доступу: http://socportal.info/2015/08/06/chim-ukrayinizagrozhuye-reforma-zaliznitsi.html

19 Шерепа, К. Аналіз функціонування пасажирського залізничного комплексу країни [Текст] / К. Шерепа // Збірник наукових праць ДЕТУТ. Серія «Економіка і управління». - 2012. Вип. 19. - С.231-235.

УДК 330.34:656.2

\title{
КОНЦЕПТУАЛЬНІ ЗАСАДИ ІНФРАСТРУКТУРНОЇ БЕЗПЕКИ НА ЗАЛІЗНИЧНОМУ ТРАНСПОРТІ
}

\author{
Шраменко О.В., к.е.н., доцент, \\ Хорошаєва С.В., магістр (УкрДУЗТ)
}

В статті показана значущість транспортної інфраструктури в сучасних умовах. Відмічено, щзо іï розвиток $\epsilon$ передумовою для формування глобального світового господарства. Обтрунтовано необхідність створення системи інфраструктурної безпеки залізничного транспорту. Наведено ризики інфраструктури, що порушують ї̈ безпеку. Надано характеристику основним видам інфраструктурної безпеки. Виділено принщипи та підходи забезпечення безпеки на залізничному транспорті.

Ключові слова: безпека, інфраструктура, залізничний транспорт.

(C) Шраменко О.В., Хорошаєва С.В.
Вісник економіки транспорту і промисловості № 57, 2017 97 